\title{
The SME Condition During Covid 19 Pandemic: Financial And Business Overview
}

\author{
Khalisa Rahmina Suryani ${ }^{1}$, Rizka Zulfikar ${ }^{1}$, Aida Vitria ${ }^{1}$ \\ ${ }^{1}$ Faculty Of Economic, Islamic University Of Kalimantan MAB Banjamasin \\ Coresponding Author \\ Email : rizkazulfikar@gmail.com
}

\begin{abstract}
.
The Covid-19 outbreak has become a global problem and has caused economic problems in various sectors including the SME sector. This research was conducted to examine the impact of the Covid-19 pandemic on the business conditions of SMEs which later can be used by policy makers in determining the right actions to overcome financial problems in the SME sector.

This research was conducted in the province of South Kalimantan using primary data. Sampling was done by purposive sampling with an instrument in the form of a questionnaire. This study used a sample of 233 respondents. The data analysis technique was performed using the analysis of the validity and reliability of the instrument and quantitative descriptive analysis to describe the financial conditions of SMEs and the affected business / corporate sectors. The results of this study found that (1) There was a significant difference to the financial condition of SMEs before and after the pandemic, where there was a decrease in gross income (-41.6\%) and the level of profit in the SME sector (-62.8\%) in general (2) Some of the impacts of the Covid Pandemic -19 regarding the business conditions of SMEs, namely (a) there are still many SMEs that have not been able to sell online, (b) there has been an increase in raw materials, (c) the majority of SMEs have difficulty obtaining raw materials, (d) there is a decrease in motivation and work productivity which is significant, (e) there are still many SMEs that experience a shortage of cash and many SMEs are in arrears of liabilities, (f) but the majority of SMEs still believe they will survive and pass the pandemic.
\end{abstract}

\section{INTRODUCTION}

Keywords : covid-19, pandemic, SMEs, financial, business condition

South Kalimantan is one of the provinces in Indonesia whose exposure to the global economy is quite high. The US-China trade war and weakening global demand certainly had an impact on the economic slowdown in South Kalimantan (South Kalimantan). On the other hand, when the global downturn has not ended, now the world economy is again hit by the Coronavirus storm or COVID-19, which has the center of its distribution in China.

During the COVID-19 pandemic, South Kalimantan's economic growth was felt to be slowing down and the prices of export commodities were getting worse, and the coal and crude oil price indexes are expected to fall further. In addition, the decreasing exchange rate of the rupiah against the dollar could adversely affect the economic situation in South Kalimantan [1].

Even through business projections using the signal method, the results show that South Kalimantan has the potential for a crisis [1]. This is also based on conditions before the COVID-19 outbreak, South Kalimantan experienced negative growth in key commodities. There was a negative growth in exports to main export destination countries such as India and Japan which was above $-10 \%$, except for China which was still around $-10 \%$. In the future, the negative side will be even greater with the Corona virus, even though the two countries, namely India and Japan, have a share of the South Kalimantan export market of around $30 \%$ and added to China around $60 \%$. Various economic indicators in South Kalimantan are not encouraging due to the slowing world economy. Economic growth in South Kalimantan will grow but slow down, it is estimated that it will only grow between 3-4.5\% under existing conditions and if there is no policy breakthrough [1].

The handling of problems that have occurred or potential problems that arise at a later date is very much dependent on the capacity of the government in managing the current crisis [2]. Readiness in dealing with COVID-19, which is the upstream of other problems, is the key to solving other problems [3]. The 
appropriate stimulus policy in terms of programs and targets determines the impact received by the community [4].

During the COVID-19 pandemic, Indonesia's economic growth experienced a slowdown due to various factors, such as a decline in export-import performance, household consumption that was still growing high and investment that was growing slowly [4]. Indonesia's economic growth is predicted to be in the range of minus 2 percent to 2 percent. This figure can be achieved if the government takes stricter steps in preventing the transmission of the Corona virus so that economic conditions continue to decline [5].

Some steps that can be considered to be taken in dealing with the economic impact of COVID-19 include [6] (a) The government needs to provide a stimulus for households. The creative economy at the household level must be encouraged. Household scale goods and services that can provide great benefits to other communities are expected to be promoted so that they can increase the income of the poor and vulnerable, (b) The government needs to make a low cost breakthrough for all public services for all people. Revitalizing social safety nets (JPS), as well as preparing various stimuli that are not cash in nature but can be enjoyed by all the poor, (c) At the macroeconomic level the government still needs to encourage inclusive economic growth, maintain price stability, create productive employment, maintain the climate investment, maintaining trade regulations, spurring growth in the agricultural sector, and developing infrastructure in underdeveloped areas and (d) Providing stimulus for industry with the aim of maintaining worker liquidity [7]. Based on the above background, this research was conducted to examine the impact of the COVID-19 pandemic on the financial condition of SMEs as the most affected sector which can then be used as material for local government considerations to formulate policies to deal with the impact of the COVID-19 pandemic.

\section{METHOD}

This research was conducted in the province of South Kalimantan, Indonesia. This type of research is a quantitative descriptive study. The type of data used is primary data with a research instrument in the form of a questionnaire. Sampling was taken by purposive sampling using 233 respondents.

The quantitative data analysis techniques carried out were (1) instrument validity-reliability analysis to measure the level of validity and reliability of the instrument and (2) normality test and difference test, (3) quantitative descriptive analysis to describe the distribution of respondents and business conditions during the Covid-19 pandemic.

\section{RESULT AND DISCUSSION}

\section{Instrumen validity and Relibility Test}

The instrument testing stage was carried out to see the level of validity and reliability of the questionnaire as a research instrument used for further activities. The results of testing the validity of the contents of the questionnaire are presented in table 1 below:

Table 1. Instrument Validity Test Results

\begin{tabular}{|c|l|r|r|c|}
\hline No & \multicolumn{1}{|c|}{ Statement } & \multicolumn{3}{|c|}{ ValidityResult } \\
\cline { 3 - 5 } & & $\begin{array}{c}\text { Pearson } \\
\text { Correlatio } \\
\text { n }\end{array}$ & Sig. & Conclusion \\
\hline 1 & UMKM_1 & $0-.180$ & 0.028 & Valid \\
\hline 2 & UMKM_2 & 0.548 & 0.000 & Valid \\
\hline 3 & UMKM_3 & 0.599 & 0.000 & Valid \\
\hline 4 & UMKM_4 & 0.720 & 0.000 & Valid \\
\hline 5 & UMKM_5 & 0.734 & 0.000 & Valid \\
\hline 6 & UMKM_6 & 0.677 & 0.000 & Valid \\
\hline 7 & UMKM_7 & 0.737 & 0.000 & Valid \\
\hline 8 & UMKM_8 & 0.345 & 0.000 & Valid \\
\hline
\end{tabular}

https://ijstm.inarah.co.id 


\begin{tabular}{|c|l|r|r|c|}
\hline 9 & UMKM_9 & 0.354 & 0.000 & Valid \\
\hline 10 & UMKM_10 & 0.510 & 0.000 & Valid \\
\hline 11 & UMKM_11 & 0.482 & 0.000 & Valid \\
\hline 12 & UMKM_12 & 0.216 & 0.008 & Valid \\
\hline 13 & UMKM_13 & 0.229 & 0.015 & Valid \\
\hline 14 & UMKM_14 & 0.232 & 0.013 & Valid \\
\hline 15 & UMKM_15 & 0.343 & 0.000 & Valid \\
\hline 16 & UMKM_16 & 0.432 & 0.000 & Valid \\
\hline 17 & UMKM_17 & 0.549 & 0.000 & Valid \\
\hline 18 & UMKM_18 & 0.549 & 0.000 & Valid \\
\hline 19 & UMKM_19 & 0.153 & 0.106 & Valid \\
\hline 20 & UMKM_20 & 0.562 & 0.000 & Valid \\
\hline 21 & UMKM_21 & 0.249 & 0.008 & Valid \\
\hline 22 & UMKM_22 & 0.421 & 0.000 & Valid \\
\hline
\end{tabular}

Based on the data above, it can be seen that the 22 items of the questionnaire questions have a significance value $<0.05$ and are considered valid to be used as a research instrument, while the results of the questionnaire reliability test are presented in table 2 .

Table 2. Reability Test Result

\begin{tabular}{|c|c|c|}
\hline Questionarie & $\begin{array}{c}\text { Cronbach's } \\
\text { Alpha }\end{array}$ & N of Items \\
\hline No. 1 - 22 & 0.909 & 22 \\
\hline
\end{tabular}

According to the Cronbachs alpha value, it can be seen that the research instrument has a reliability value of $>$ 0.90 and is included in the category of instruments with high reliability.

\section{Respondents Characteristics}

After the questionnaire test stage was carried out and it was confirmed that there were no revisions to the statement in the questionnaire. In the next data collection stage, 233 from the SME sector with the characteristics of the respondents as show in table 3

Table 3. Characteristics of Respondents

\begin{tabular}{|c|c|c|c|c|c|}
\hline Characteristics & Freq & $\%$ & Characteristics & Freq & $\%$ \\
\hline Business fields & & & $\begin{array}{l}\text { Number of } \\
\text { employees }\end{array}$ & & \\
\hline Small-Market Trader & 13 & $5.6 \%$ & Under 3 people & 118 & $50.6 \%$ \\
\hline Micro business & 29 & $12.4 \%$ & $3-5$ people & 109 & $46.8 \%$ \\
\hline Small business & 75 & $32.2 \%$ & $6-10$ people & 4 & $1.7 \%$ \\
\hline Agricultural Sector & 30 & $12.9 \%$ & 11-20 People & 0 & $0.0 \%$ \\
\hline Plantation Sector & 14 & $6.0 \%$ & Above 20 People & 2 & $0.9 \%$ \\
\hline Livestocks sector & 27 & $11.6 \%$ & Total & 233 & $100.0 \%$ \\
\hline Fishery Sector & 28 & $12.0 \%$ & & & \\
\hline Free / Service & & & Social & & \\
\hline Workers (Pedicab, & & & Assistance & & \\
\hline Ojek, Ojol, etc.) & 2 & $0.9 \%$ & & & \\
\hline Restaurant & 2 & $0.9 \%$ & As recipient & 76 & $32.6 \%$ \\
\hline Construction service & 2 & $0.9 \%$ & Not the recipient & 157 & $67.4 \%$ \\
\hline Others & 11 & $4.7 \%$ & Total & 233 & $100.0 \%$ \\
\hline \multirow[t]{2}{*}{ Total } & 233 & $100.0 \%$ & & & \\
\hline & & & $\begin{array}{l}\text { Type of Social } \\
\text { Assistance }\end{array}$ & & \\
\hline
\end{tabular}




\begin{tabular}{|c|c|c|c|c|c|}
\hline Length of Business & & & Business & & \\
\hline & & & Assistance & 62 & $81.6 \%$ \\
\hline Under 2 Years & 26 & $11.2 \%$ & JPS & 10 & $13.2 \%$ \\
\hline 25 years & 143 & $61.4 \%$ & Others & 4 & $5.3 \%$ \\
\hline $6-10$ years & 43 & $18.5 \%$ & Amount & 76 & $100.0 \%$ \\
\hline 11-20 Years & 15 & $6.4 \%$ & & & \\
\hline Above 20 Years & 6 & $2.6 \%$ & Liabilities / Debt & & \\
\hline Total & 233 & $100.0 \%$ & Have Liabilities & 52 & $22.3 \%$ \\
\hline & & & Have no & & \\
\hline & & & Liabilities & 181 & $77.7 \%$ \\
\hline & & & Total & 233 & $100.0 \%$ \\
\hline
\end{tabular}

Based on the data above, the characteristics of the research respondents are as follows:

1. The business fields that the respondents are engaged in include small-market traders (5.6\%), microbusinesses (12.4\%), small businesses $(32.2 \%)$, plantation sector $(6.0 \%)$, livestock sector $(11.6 \%)$, fisheries sector (12.0\%), casual workers (pedicab drivers, motorcycle taxis, ojl, etc.) $(0.9 \%)$, restaurants $(0.9 \%)$, and other workers (online pedagogues, brokers, etc.) $(4.7 \%)$.

2. The length of the SME business includes having been doing business under 2 years $(11.2 \%)$, doing business between $2-5$ years $(61.4 \%)$, between 6-10 years $(18.5 \%)$, between $11-20$ years $(6.4 \%)$ and have been doing business for over 20 years $(2.6 \%)$.

3. The number of SME workforce includes having a workforce of less than 3 people (50.6\%), between 35 people (46.8\%), between 6-10 people (1.7\%), between $11-20$ people $(0.0 \%)$ and have a workforce of more than 20 people $(0.9 \%)$.

4. Respondents who have received Bansos are as much as $36.2 \%$ while $67.4 \%$ have never received Bansos.

5. Types of social assistance received by respondents included business assistance (81.6\%), social safety nets $(13.2 \%)$ and other types of social assistance (5.3\%).

6. Respondents who have obligations / debts to third parties as much as $22.3 \%$. Meanwhile, the remaining $77.7 \%$ has no obligations / debts to third parties.

\section{Financial Condition}

Covid-19 Pandemic has had an impact on changes in income and cost structures. A comparison of the financial conditions of the SME sector before and after the Covid-19 pandemic is presented in table 4and Figure 1.

Table 4. Income and Costs Structure Comparison Before and After the Covid-19 Pandemic

\begin{tabular}{|c|c|c|c|c|c|}
\hline \multirow[t]{2}{*}{ No } & \multirow[t]{2}{*}{ Uraian } & \multicolumn{2}{|c|}{ Million Rp } & \multirow[b]{2}{*}{ Variance } & \multirow[b]{2}{*}{$\%$} \\
\hline & & $\begin{array}{c}\text { Before } \\
\text { Pandemic }\end{array}$ & $\begin{array}{c}\text { After } \\
\text { Pandemic }\end{array}$ & & \\
\hline 1 & Gross Income & 722.806 & 421.950 & $(300.856)$ & $-41.6 \%$ \\
\hline 2 & $\begin{array}{l}\text { Additional } \\
\text { Income }\end{array}$ & 66.180 & 32.800 & $(33.380)$ & $-50.4 \%$ \\
\hline 3 & $\begin{array}{l}\text { Electricity and } \\
\text { Water Cost }\end{array}$ & 29.885 & 20.142 & (9.743.) & $-32.6 \%$ \\
\hline 4 & Liabilities & 71.468 & 65.826 & $(5.642)$ & $-7.9 \%$ \\
\hline 5 & Employee Cost & 29.150 & 21.850 & (7.300) & $-25.0 \%$ \\
\hline 6 & $\begin{array}{l}\text { Operational } \\
\text { Cost }\end{array}$ & $99,126,000$ & $138,776,400$ & 39.650 & $40.0 \%$ \\
\hline 7 & $\begin{array}{l}\text { Non Operational } \\
\text { Cost }\end{array}$ & $66,920,000$ & $40,080,000$ & $(26.840)$ & $-40.1 \%$ \\
\hline
\end{tabular}




$8 \quad$ Net Profit $\quad 559,356,960 \quad 208,155,450 \quad(351.202) \quad-62.8 \%$

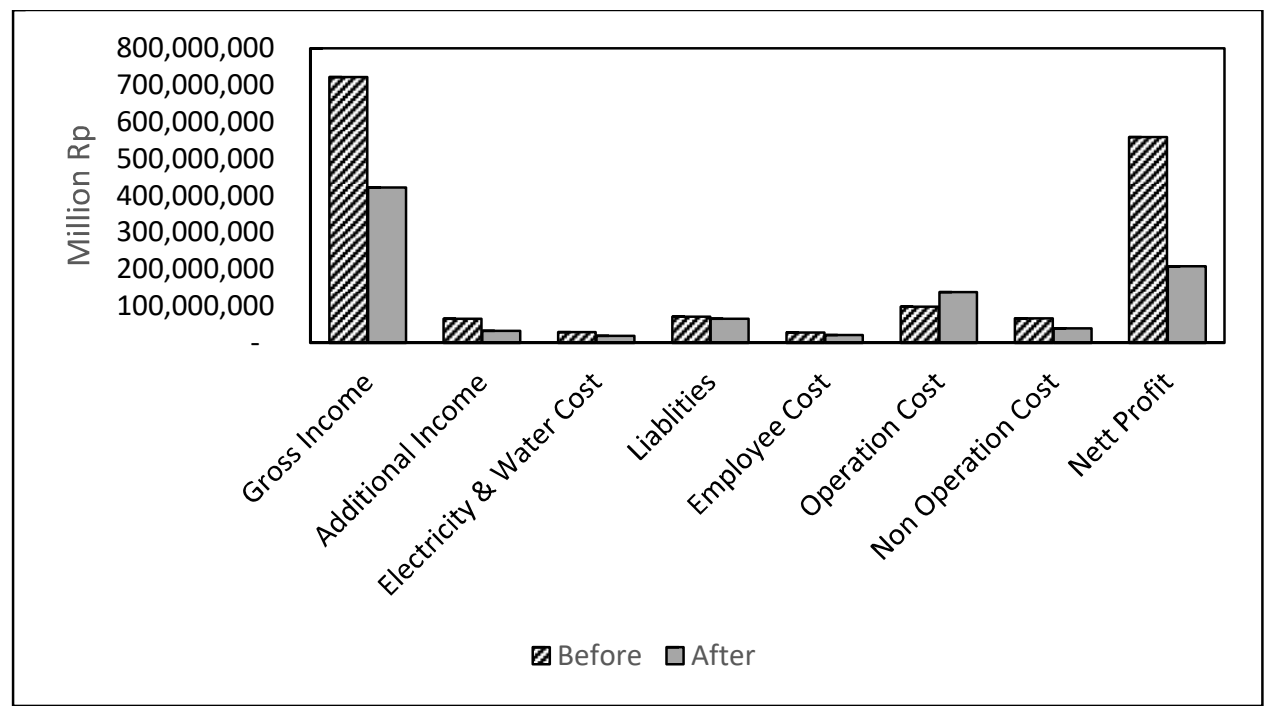

Fig 1. Income and Cost Structure Comparison Before and After Pandemic Covid-19

Based on the table above, the changes in income and cost structure in the SME sector are as follows:

- The gross income of the SME sector has decreased by $41.6 \%$ after the Covid-19 pandemic as well as additional income which has also decreased by $50.4 \%$.

- Changes in the cost structure in the SME sector have also occurred since the Covid-19 pandemic, including:

- There was a decrease in the cost of electricity and water in the SME sector by $32.6 \%$.

- Costs incurred to pay obligations decreased by $7.9 \%$ which was probably due to the process of rescheduling obligations or lowering the interest rate on the part of the lender.

- Costs incurred to pay employee wages or salaries have decreased by $25 \%$ which could be due to a policy to reduce employees in the SME sector

- Costs incurred for operational activities increased by $40 \%$ while non-operating costs decreased by $40.1 \%$.

In general, the level of net profit in SME sector due to the Covid-19 pandemic has decreased by $62.8 \%$. Therefore, SMEs need to manage [8] and minimize Business Cost during a Pandemic by designing and implementing a cost control measure or controlling expenses to minimize expenses (Cost Reduction) [9], increasing the visibility of expenditure while reducing total expenditure (Spend Management) and optimize both processes; cost reduction and spend management [10].

\section{Normality and Differencies Test}

The data analyzed in the form of net profit before and after the Covid-19 pandemic were tested for the normal distribution of the data using the Normality Test (Kolmogrov Smirnov and Shapiro-Wik Test). The results of the normality test are presented in table 5 .

Table5. Normality Test Result

\begin{tabular}{llrrrrrr}
\hline & \multicolumn{2}{l}{ Before_Af } & \multicolumn{3}{c}{ Kolmogorov-Smirnov $^{\mathrm{a}}$} & \multicolumn{3}{c}{ Shapiro-Wilk } \\
& ter & Statistic & \multicolumn{1}{c}{ Df } & \multicolumn{1}{c}{ Sig. } & Statistic & \multicolumn{1}{c}{ df } & \multicolumn{1}{c}{ Sig. } \\
\hline Net_Prof & 1.00 & .262 & 233 & .000 & .603 & 233 & .000 \\
it & 2.00 & .222 & 51 & .000 & .746 & 51 & .000 \\
\hline
\end{tabular}

a. Lilliefors Significance Correction

Based on the Kolmogrov Smirnov and Shapiro-Wik tests, a significance value was obtained $(0.000)<0.05$, which means that the data was distributed abnormally, so that the data differential test was carried out using 
the non-parametric statistical method, namely using the Mann-Whitney U Test. The results of the Mann Whitney U Test are presented in table 6.

Table 5. Mann-Whitney U Test Result

\begin{tabular}{l|r}
\hline & Net_Profit \\
\hline Mann-Whitney U & 3350.000 \\
Wilcoxon W & 4676.000 \\
Z & -4.879 \\
Asymp. Sig. (2- & .000 \\
tailed) & \\
\hline
\end{tabular}

a. Grouping Variable:

Before_After

According to the results of the Mann-Whitney U Test, it can be seen that the significance value is $(0.000)$ $<0.05$, which means that there is a very significant difference between net profit before and after pandemic.

\section{Business Conditions}

The impact of the Covid-19 pandemic on SMEs can also be viewed from several aspects, including the following:

\section{1) Demand Rate}

The impact of the Covid-19 pandemic has an impact on the level of demand for SME products (Figure 2), where $96.1 \%$ of SMEs stated that there was a decrease, $3.9 \%$ stated that there was no change in demand and none of the SMEs $(0 \%)$ stated that the level of demand had increased. This condition is because during a pandemic, consumers will tend to ignore prices and pay more attention to value [11]. Consumers as much as possible hold their money and will buy goods that are considered to have very important value [12].

\section{2) Ability to Sell Products Online}

In selling online (Figure 3), only $15.2 \%$ of SMEs stated that they were able to sell online, while the remaining $84.8 \%$ stated that they did not have the ability to sell online.Things that were expressed were, among others, because they did not have the expertise / knowledge (19.6\%), did not have facilities $(8.0 \%)$ and the remaining $72.5 \%$ stated that the reason was because it was not possible both because of the network and business characteristics (Figure 4).

Currently, there are actually many digital applications that make it easier for SME players to transact. Unfortunately, there are also many SME players who are unfamiliar with technological developments. In fact, to survive in the midst of this pandemic, SMEs must be willing to enter the digital world [13].

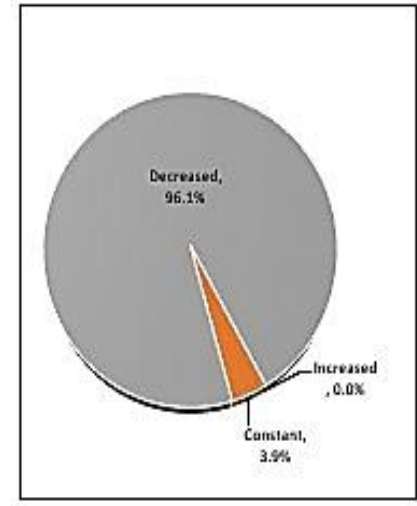

Figure 2. SMEs product demand during Pandemic

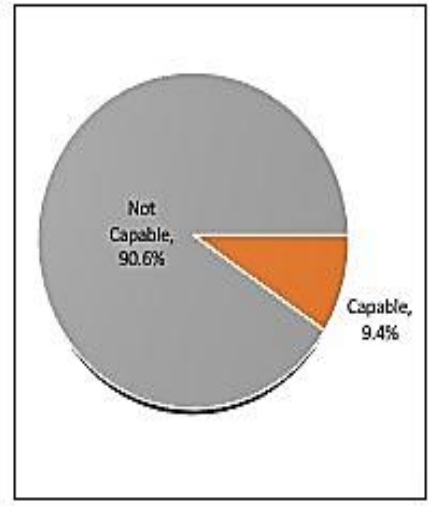

Figure 3. SMEs Capability to selling product online 


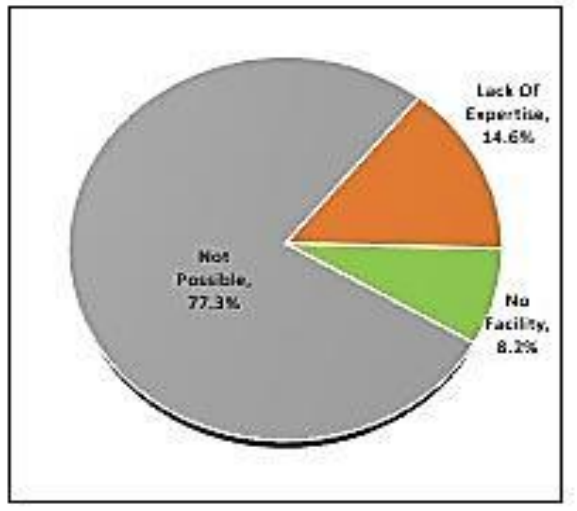

Figure 4. SMEs Obstacles To Sell Product Online During Pandemic

\section{3) Raw Material Prices}

During the Covid-19 Pandemic, $72.1 \%$ of SMEs stated that there was an increase in raw materials (Figure 5), $23.2 \%$ stated that the price of raw materials had not changed and the remaining $4.7 \%$ stated that there was a decrease in raw material prices during the Covid-19 pandemic.

The phenomenon of an increase in raw material prices occurs due to a decrease in the number of shipments during the lockdown [14], which causes an increase in raw material prices by up to $30 \%$ which makes it even more difficult for business actors to obtain raw materials for business continuity during a pandemic [15].

\section{4) Access to Raw Materials}

In obtaining raw materials (Figure 6), as many as $10.3 \%$ of SMEs stated that they were experiencing difficulties, $36.1 \%$ of SMEs stated that there was no change between conditions before and after the Covid19 Pandemic and as many as $53.6 \%$ of SMEs stated that it was easier to get raw materials.

A common problem faced by industry during the pandemic is the difficulty of obtaining raw materials [16], one of which is the increase in the cost of transporting raw materials [17] especially if the industry uses imported raw materials [18]

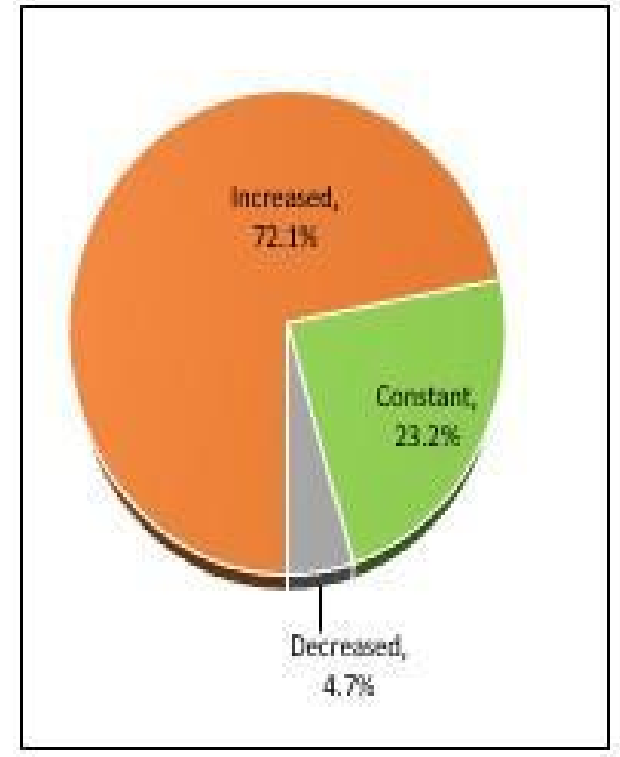

Figure 5. Raw Material Price During Pandemic

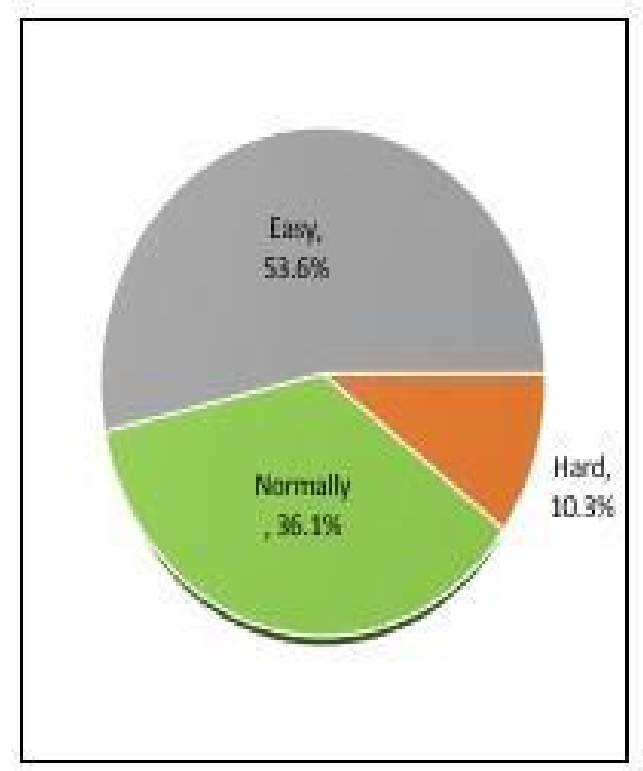

Figure 6. SME's easiness To get Raw Materials During Pandemic 


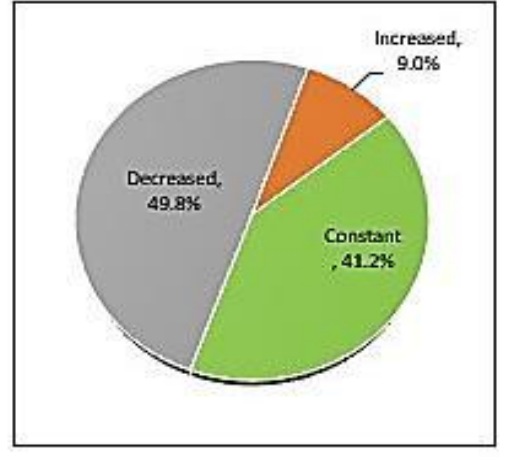

Figure 7. SME's Work Motivation During Pandemic

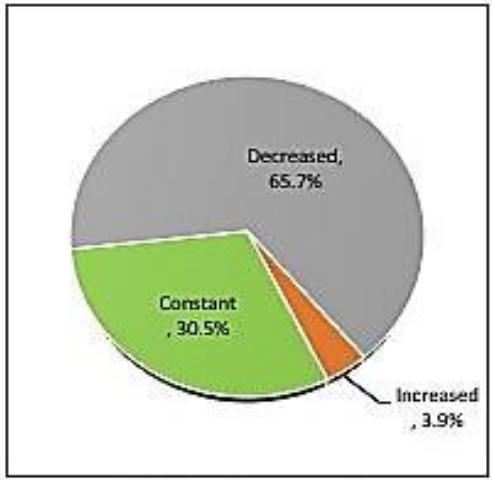

Figure 8. Work Productivity During Pandemic

\section{5) Work Motivation}

During the Covid-19 Pandemic, as many as $49.8 \%$ of SMEs stated that there was a decrease in work motivation (Figure 7), $41.2 \%$ of SMEs stated that there was no change in work motivation and the remaining $9.0 \%$ of SMEs actually stated that there was an increase in work motivation during the Pandemic.

There was a significant change in work motivation during the Pandemic due to the increasing stress levels of workers [19].

\section{6) Productivity}

During the Covid-19 Pandemic, as many as $65.7 \%$ of SMEs stated that there was a decrease in productivity (Figure 8 ), 30.5\% of SMEs stated that there was no change in productivity and the remaining 3.9\% of SMEs actually stated that there was an increase in productivity during the Pandemic. The increasing stress level of workers and company owners also triggers a decrease in work productivity during a pandemic [19], [20].

\section{7) Conditions of Cash}

During the Covid-19 Pandemic, as many as $71.7 \%$ of SMEs stated that they had a shortage of cash (Figure 9), as many as $27.9 \%$ of SMEs stated that they had sufficient cash while the remaining $0.4 \%$ of SMEs actually had more cash. The occurrence of a short of cash condition is mostly caused by decreased income, while the costs incurred tend to remain constant [21].

8) Debt / Liability Conditions As many as $48.6 \%$ of SMEs were in arrears during the Covid-19 Pandemic (Figure 10), consisting of $19.2 \%$ of SMEs in arrears under 3 months and $28.8 \%$ of SMEs having arrears of more than 3 months. Meanwhile, the remaining 51.9\% are in good condition without arrears.

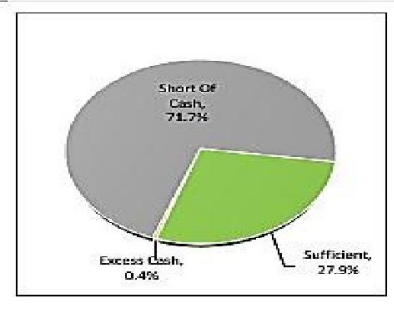

Figure 9. Adequacy of Cash Durine Pandemic

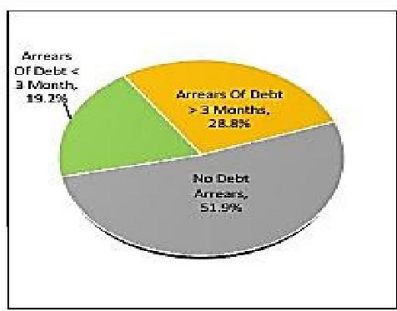

Figure 10. Liabilities Condition During Panderric

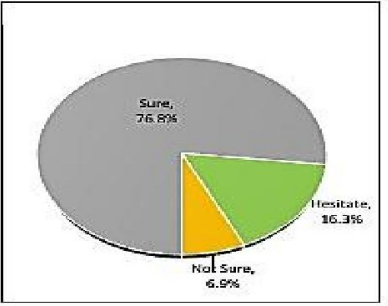

Figure 11. SME's confidence will survive during pandemic

\section{9) Belief that Businesses Will Survive During the Covid-19 Pandemic}


As many as $69.6 \%$ of SMEs still believe that their business will survive during the Covid-19 Pandemic (Figure 11), 18.8\% expressed doubts and the remaining 11.6\% stated that they are not sure that their business will survive during the Covid-19 Pandemic.

\section{CONCLUSION}

Based on the results of our study, the financial and business conditions of SMEs during the Pandemic include (1) There is a significant difference between the net profit before and after the pandemic, where there is a decrease in gross income (-41.6\%) and the profit rate of the SME sector (-62.8\%) ) in general, this is due to a decrease in the level of sales due to decreased public demand and purchasing power due to the conditions of the Covid-19 Pandemic, (2) The impact of the Covid-19 pandemic has an impact on the level of demand for SME products, where $96.1 \%$ of SMEs stated that there was a decrease, $3.9 \%$ stated there was no change in demand and none of the SMEs $(0 \%)$ stated that the level of demand had increased. (3) Some of the impacts of the Covid-19 Pandemic on the business conditions of SMEs, namely (a) there are still many SMEs that have not been able to sell online, (b) there has been an increase in raw materials, (c) the majority of SMEs are experiencing difficulties in obtaining raw materials, (d) ) there is a significant decrease in work motivation and productivity, (e) there are still many SMEs that experience a shortage of cash and many SMEs are in arrears of obligations, (f) but the majority of SMEs still believe that they will survive during the pandemic.

\section{REFERENCES}

[1]. Imansyah, H. 2020. Dampak Penyebaran Virus Corona terhadap Perekonomian Kalsel. Available at https://iesp.ulm.ac.id/agenda-diskusi-bagaimana-dampak-penyebaran-virus-corona-terhadap-perekonomian$\underline{\text { kalsel/ }}$

[2]. Correia, S., Luck, S., \& Verner, E. (2020). Fight the pandemic, save the economy: Lessons from the 1918 flu. Federal Reserve Bank of New York, 5.

[3]. Stellinger, A., Berglund, I., \& Isakson, H. (2020). How trade can fight the pandemic and contribute to global health. COVID-19 and Trade Policy: Why Turning Inward Won't Work, 21.

[4]. Liu, D., Sun, W., \& Zhang, X. (2020). Is the Chinese economy well positioned to fight the COVID-19 pandemic? The financial cycle perspective. Emerging Markets Finance and Trade, 56(10), 2259-2276.

[5]. INDEF, 2020. Teori Tindakan Kolektif dan Peran Masyarakat untuk Mengatasi Pandemi Covid-19. Available at $\quad$ https://indef.or.id/update/detail/kuliah-umum-teori-tindakan-kolektif-dan-peran-masyarakat-untukmengatasi-pandemi-covid-19.

[6]. CORE, 2020. Dampak Ekonomi Covid-19 Bagi Indonesia. Available athttps://politik.rmol.id/read/2020/04/20/431071/prediksi-core-pengangguran-akibat-covid-19-di-indonesiabisa-bertambah-hingga-9-juta-orang.

[7]. Basrowi, B. (2020). Dampak dari Lesunya Perekonomian Akibat Wabah Corona. Available athttps://www.suara.com/yoursay/2020/03/30/151403/dampak-dari-lesunya-perekonomian-akibat-wabahcorona

[8]. Bernheim, B. D., \& Taubinsky, D. (2018). Behavioral public economics. In Handbook of Behavioral Economics: Applications and Foundations 1 (Vol. 1, pp. 381-516). North-Holland.

[9]. Obal, M., \& Gao, T. (2020). Managing business relationships during a pandemic: Conducting a relationship audit and developing a path forward. Industrial Marketing Management, 88, 247-254.

[10]. Broughel, J., \& Kotrous, M. (2021). The Benefits of Coronavirus Suppression: A Cost-Benefit Analysis of the Response to the First Wave of COVID-19 in the United States. Covid Economics, 67, 128-171.

[11]. Nikolopoulos, K., Punia, S., Schäfers, A., Tsinopoulos, C., \& Vasilakis, C. (2021). Forecasting and planning during a pandemic: COVID-19 growth rates, supply chain disruptions, and governmental decisions. European Journal of Operational Research, 290(1), 99-115.

[12]. Sharma, P., Leung, T. Y., Kingshott, R. P., Davcik, N. S., \& Cardinali, S. (2020). Managing uncertainty during a global pandemic: An international business perspective. Journal of business research, 116, 188-192.

[13]. Turaev, I., \& Ganiev, F. (2021). Management Strategy of Small and Medium Enterprises during the Pandemic Covid-19. Journal La Bisecoman, 2(1), 7-12. 
[14]. Susilawati, S., Falefi, R., \& Purwoko, A. (2020). Impact of COVID-19's Pandemic on the Economy of Indonesia. Budapest International Research and Critics Institute (BIRCI-Journal): Humanities and Social Sciences, 3(2), 1147-1156.

[15]. Wang, D., Hubacek, K., Liang, X., Coffman, D. M., Hallegatte, S., \& Guan, D. (2021). Reply to: Observed impacts of the COVID-19 pandemic on global trade. Nature Human Behaviour, 1-2.

[16]. Wang, D., Hubacek, K., Liang, X., Coffman, D. M., Hallegatte, S., \& Guan, D. (2021). Reply to: Observed impacts of the COVID-19 pandemic on global trade. Nature Human Behaviour, 1-2.

[17]. Muley, D., Shahin, M., Dias, C., \& Abdullah, M. (2020). Role of transport during outbreak of infectious diseases: evidence from the past. Sustainability, 12(18), 7367.

[18]. Alfonso, V., Boar, C., Frost, J., Gambacorta, L., \& Liu, J. (2021). E-commerce in the pandemic and beyond. BIS Bulletin, 36 .

[19]. Shabuur, M. I., \& Mangundjaya, W. L. (2020). Pengelolaan stres dan peningkatan produktivitas kerja selama work from home pada masa pandemi covid-19. Jurnal Psikologi Udayana, 7(2), 93-109.

[20]. Susilowati, N. (2020). Produktivitas Jamu Pada Masyarakat Argomulyo Di Masa Pandemi. Jurnal Ekonomi \& Pendidikan, 17(2).

[21]. Pratiwi, E. T., \& Jasiyah, R. (2021, February). PENINGKATAN SUMBER DAYA MANUSIA, DIGITAL MARKETING, DAN PENGELOLAAN KAS PELAKU UMKM SAAT PANDEMI COVID-19. In Seminar Nasional ADPI Mengabdi Untuk Negeri (Vol. 2, No. 2, pp. 13-18). 